\title{
Financing micro-entrepreneurs for poverty alleviation: a performance analysis of microfinance services offered by BRAC, ASA, and Proshika from Bangladesh
}

\author{
Dilruba Khanam", Muhammad Mohiuddin ${ }^{2 *}$, Asadul Hoque ${ }^{3}$ and Olaf Weber ${ }^{4}$
}

\footnotetext{
* Correspondence: mmohiuddin@ tru.ca

${ }^{2}$ School of Business and Economics, Thompson Rivers University, Kamloops, BC V2C 0C8, Canada Full list of author information is available at the end of the article
}

\begin{abstract}
Microfinance services have emerged as an effective tool for financing microentrepreneurs to alleviate poverty. Since the 1970s, development theorists have considered non-governmental microfinance institutions (MFIs) as the leading practitioners of sustainable development through financing micro-entrepreneurial activities. This study evaluates the impact of micro-finance services provided by MFIs on poverty alleviation. In this vein, we examine whether microfinance services contribute to poverty alleviation, and also identify bottlenecks in micro-finance programs and operations. The results indicate that the micro-loans have a statistically significant positive impact on the poverty alleviation index and consequently improve the living standard of borrowers by increasing their level of income.
\end{abstract}

Keywords: Poverty alleviation, Microcredit, NGOs, Sustainable rural development, Developing country, Bangladesh

JEL classification: C13

\section{Background}

Poverty alleviation is one of the most important components of Sustainable development goal (SDG) of United Nation (UN). Financing micro-entrepreneurs for job creation and income generating activities shows some success in many developing countries. The link between poverty and natural environment is often mentioned in the 'sustainable development' debate (Reardon and Vosti 1995). Consequently, poverty alleviation is necessary to deal with by any effective program related to sustainable development (Chokor 2004; Duraiappah 1998). Since the 1990s, poverty alleviation has been among the top priorities of international development (Develtere and Huybrecht 2005), because one fifth of the world population are living in extreme poverty (Hermes and Lensink 2007b). For instance, about 2.5 billion people live on less than $\$ 2$ a day (Bruton et al. 2011). The plan of the Sustainable Development Goals (SDG) is only one of the programs aiming to eradicate poverty and to end hunger (UN 2015).

Furthermore, more than half of the world's working-age adults (about 2.5 billion) still do not have access to financial services of regulated financial institutions (Fouillet et al. 2013).

(c) The Author(s). 2018 Open Access This article is distributed under the terms of the Creative Commons Attribution 4.0 International License (http://creativecommons.org/licenses/by/4.0/), which permits unrestricted use, distribution, and reproduction in any medium, provided you give appropriate credit to the original author(s) and the source, provide a link to the Creative Commons license, and indicate if changes were made. 
Therefore, a good number of working-age adults around the world depend on informal moneylenders for loans to start or maintain a micro-enterprise. Globally, there are more than 3100 microfinance institutions (MFIs) providing loans to over 100 million clients to lift them out of poverty (Cull et al. 2011; Epstein and Yuthas 2011; Hartarska and Nadolnyak 2007). Financing micro-entrepreneurs with small, but collateral free loans, has emerged as a promising and effective tool for alleviating poverty (Baklouti 2013), as it focuses on providing credit services to the poor, yet income generating ventures without collaterals (Hermes et al. 2011; Quayes 2012).

In the past 25 years, microfinance service has been considered as one of the most significant innovations in development policy around the world (Ahlin and Jiang 2008; Elahi and Rahman 2006). Microfinance service offers not only the microcredit but also the allied services such as consulting and training for the microenterprises as well as market information and access to wider market which is very often not in reach of micro-entrepreneurs due to their lack of knowledge and bureaucratic hurdles. Since the last decade, the role of microfinance has received significant attention, from both policy makers as well as academics (Bartual Sanfeliu et al. 2013; Hermes and Lensink 2007a; Ingham et al. 2013; Knight et al. 2009). Therefore, microfinance can contribute to the Sustainable Development Goals such as gender equality by empowering women through microfinance (Hermes and Lensink 2011; Lock and Lawton Smith 2016; Weber and Ahmad 2014) and through the provision of financial capital to promote sustained and inclusive economic growth (Zapalska et al. 2017). Strategically, microfinance plays a vital role for the poor to raise their own microenterprises to escape from poverty (Al-Mamun et al. 2014a; Imai et al. 2012; Matin et al. 2002).

Micro-finance services have potential for equitable and sustainable development (Garikipati 2008; Hermes and Lensink 2011; Kabeer 2001; Rahman 1999) and in addition to providing those in need with financial capital, many microfinance institutions focus on gender equality, which is another key goal of sustainable development (Khan 1995; Rahman 1999; Rankin 2002; Smyth 2007; Weber and Ahmad 2014). The micro-credit scheme of Grameen Bank of Bangladesh, providing micro-loans to landless poor women in rural areas of Bangladesh, for instance, became a successful equitable and sustainable development initiative (Dowla 2006; Karim 2008; Khandker 2005; Mohiuddin 2000). A similar and successful approach is followed by the Pakistani micro-finance institution-Kashf Foundation that exclusively lends to women and increases their empowerment (Weber and Ahmad 2014). Because women are the central actors, particularly, of rural livelihood activities. Women centric income generating activities strengthen their role in sustainable development as indicated in the Sustainable Development Goals (United Nations 2015). Ideally, poor people invest micro-loans in their micro-enterprises to generate income that ultimately help them to reduce their poverty (Karim and Osada 1998). Generally, microloans are directed towards funding both existing and start-up enterprises (Bayulgen 2008). While many microfinance institutions offer services such as training, savings facilities, family planning, health services and education (Karim and Osada 1998), interest rates of micro-loans are usually higher than those of commercial loans, but they are far below the interest rates of informal money lenders (Bayulgen 2008; Chowdhury and Chowdhury 2011). High interest rates are justified by the non-existence of any collateral, high administrative costs because of the provision of many small loans, as well as and the costs of accessing borrowers in 
rural environments (Hietalahti and Linden 2006; Mallick 2002). Generally, repayment records of micro-loans are high (Kono and Takahashi 2010), and consequently, default rates are often lower than in commercial lending. Grameen Bank, for instance, achieves repayment rates as high as $98 \%$ compared to only $27 \%$ for the Bangladeshi banks (Hudak 2012).

Since the 1970s, development theorists and practitioners have considered NGOs as leading practitioners of rural development (Muhumuza 2005). In many developing countries, such as India, Bangladesh, and Honduras NGOs provide credit services to the poor to promote self-employment and income growth (Baruah 2010; Pitt et al. 1999; Rosintan et al. 1999; Ruben and Van 2001). The objective of the current study is to evaluate the performance of microfinance services offered by three leading non-governmental Microfinance institutions (MFIs) such as BRAC, ASA and Proshika from Bangladesh. The previous studies were focused on the impact analysis of 'microcredit' programs undertaken by different kinds of associations, cooperatives, groups, credit unions and various public funded projects. The current study focuses on performance analysis of NGO-turned-microfinance institutions (MFIs) that offer not only the microcredit but also allied services to a wider clientele base.

Though microfinance is often seen as a concept useful for achieving sustainable development, it is also criticized. Because microfinance is often not regulated such that lending often happens informally and many potential borrowers are not aware of the benefits and risks of products and services offered by microfinance institutions and commercial banks. Furthermore, many are not able to access loans, mainly due to their illiteracy or knowledge in regional languages (Hasan 2012). Additionally, the credit evaluation procedures of institutionalized lenders are often stricter than those of informal lenders, and therefore prevent borrowers from asking for loans at microfinance institutions having established stricter credit risk assessment procedures (Arora and Meenu 2011). Consequently, microfinance is criticized for not serving the poorest of the poor (Brau and Woller 2004; Datta 2004; Weiss and Montgomery 2005).

In addition, though many scholars argue for microfinance being an effective tool for alleviating poverty and that commercial microfinance institutions have the same outreach and impact as their non-commercial counterparts (Hishigsuren 2007; Mersland and Strøm 2010; Yaron 1992), some see a mission drift (Aubert et al. 2009) towards a more commercial direction that focuses on financial returns for microfinance institutions rather than on poverty alleviation or empowerment (Copestake 2007). Hermes et al. (2011), for instance, found strong evidence for a negative correlation between the financial efficiency of microfinance institutions and the outreach to the poor. Their results suggest that a pure commercial approach has less impact on sustainability goals, such as poverty alleviation and empowerment. They are supported by Cull et al. (2011, 2007) who found that commercially oriented microfinance institutions tend to grant less but higher loans to richer borrowers in order to decrease costs.

The connection between microfinance and sustainability is discussed at least in three ways. Firstly, it is connected with the financial sustainability of the microfinance institution. It focuses on whether the microfinance institution is able to conduct the business without being supported by donor monies. Secondly, it is about the long-term effect of microfinance on non-financial goals such as poverty alleviation and empowerment. 
Thirdly, it deals with the connection between economic, environmental, and social effects of microfinance.

Regarding the financial sustainability of microfinance institutions, there are two main categories of microfinance institutions. The first group follows a poverty alleviation approach while the second group is based on the financial sustainability approach (Weber 2013). Many institutions from the first group are dependent on donor subsidies to manage the high costs of lending in order to maximize poverty alleviation efforts. The costs are higher because the institutions attempt to provide small loans to as many borrowers as possible. Therefore, until to date, investments in microfinance have been mainly done because of philanthropically motives (J.P. Morgan 2010). Consequently, these institutions are not able to sustain financially without financial donors.

Recently, however, microfinance has been spotlighted as an investment that creates financial returns as well (Swibel 2008). Also, conventional investors have realized that microfinance may be an investment opportunity that creates attractive financial returns. Following this approach some microfinance institutions, such as the Indian SKS Microfinance or the Mexican Compartamos, are already listed on stock exchanges in order to attract investors. Those and similar institutions follow the financial sustainability approach (Hermes and Lensink 2007a; Robinson 2001). This approach is striving to serve poor people, yet it additionally emphasises the financial sustainability of microfinance that goes along with commercial viability and institutional growth in order to lessen donor reliance and to be attractive for investors (Koveos and Randhawa 2004; Pollinger et al. 2007; Weber 2013).

Sustainability of microfinance understood as long-term effects is also discussed controversially. One group of researchers suggests that access to finance reduces poverty significantly and long-lasting through an increase of income, a diversification of sources of income, the accumulation of financial assets and other financial aspects. Consequently, an improved financial situation contributes to achieving better education, health-care, and empowerment (Hermes and Lensink 2011). The other group argues that microfinance does not have a long-term effect on poverty alleviation because it does not address the poorest of the poor (Hermes and Lensink 2007b), and because it does not contribute to developing higher levels of economic activity, yet stays at the micro-enterprise level (Ahlin and Jiang 2008; Mayoux 2001; Weber 2013). The third aspect of sustainability is about the connection between social, economic, and environmental issues, the so-called triple-bottom line (Elkington 1998). Stakeholder pressure and social responsibility have thrived the integration of environmental aspects into microfinance in recent years (Allet and Hudon 2013). Generally, however, the integration of environmental issues into micro lending or even using microloans as a means to improve the triple-bottom-line are rare with some exceptions such as, Grameen Shokti's loans for solar devices in Bangladesh (Komatsu et al. 2011).

\section{Microfinance services offered by NGO-turned-MFIs in Bangladesh}

Bangladesh is a South Asian country that has huge potential for development. It increased its ranking on the Human Development Index by 20\% between 1990 and 2015, but still about half of its population live in multidimensional poverty (UNDP 2015) with $80 \%$ in the rural areas (Ahmed 2009). 
From the eighties onward micro-credit became a successful concept in Bangladesh (Kabeer 2001). In rural communities in Bangladesh, microcredit has been introduced as a means of economic and social development (Mallick 2002). In Bangladesh, more than 20,000 NGOs, associations, credit groups and cooperatives have been operating (Ullah and Routray 2007) and about 2116 NGOs have been offering microfinance services to millions of poor rural at lower costs through informal lenders aiming to improve the borrowers' economic conditions (Mazumder and Wencong 2013; Zeller et al. 2001). Further, Bangladeshi NGOs and microfinance institutions have been working successfully with their poor clients in improving their socio-economic conditions (Ahmad and Townsend 1998). For example, Bangladesh Rural Advancement Committee (BRAC) is considered as one of the largest successful NGOs in the world (Chowdhury and Bhuiya 2004; Develtere and Huybrecht 2005) in the field of micro-finance. Consequently, Amin et al. (2003) argue that microcredit is successful at reaching the poor.

As a result, poverty alleviation programs in Bangladesh are increasingly becoming important in order to address the poverty mitigation, and many studies have been published on microfinance activities in Bangladesh, such as the growth of the institutions, their objectives and strategies of work, organizational structure, program component, credit operation, training performances, and impacts. Some studies have focused on the impacts of the programs on poverty alleviation (Kabeer 2001; Khandker 1998, 2005; Nanda 1999; Rahman 1999; David Roodman and Morduch 2009; Khanam et al. 2018; Schuler and Rottach 2010). Ullah and Routray (2007) conducted research on Bangladeshi MFIs (BRAC \& PROSHIKA); Nawaz (2010) studied BRAC \& ASA; another study (Chowdhury et al. 2005) focused on Grameen Bank, BRAC \& ASA. Yet, our study examines three leading NGO-turned micro-finance institutions (MFIs) namely; BRAC, ASA, and PROSHIKA focusing on poverty alleviation. Therefore, a slight change in the performance of any of them may affect the total performance of microfinance in Bangladesh (Hossain and Ahmed 2000). To address this academic and practical gap, we analyze the impact and performance of these three microfinance institutions (MFIs).

\section{Conceptual framework}

"Most recently, the poor have been conceptualized as a heterogeneous group of vulnerable households with complex livelihoods and varied needs" (Matin et al. 2002, p. 274). From such a perspective, microfinance can be considered as a means for achieving household priorities and reducing vulnerability and/or increasing income (Matin et al. 2002). Evidence on the impact of micro-finance on poverty in Bangladesh and in other developing countries, however, is not clear-cut. Khandker (1998), for instance, argues that access to micro-credit has the potential to significantly reduce poverty (Hermes and Lensink 2011; Khandker 1998, 2005; Martin and Hulme 2003). Similarly, Quayes (2012) results suggest a positive impact of microfinance on economic development while other studies argue that only loans for productive purposes have a positive effect on economic development (Imai et al. 2010; Vial and Hanoteau 2015). Chatterjee et al. (2018) found that group based financial services to micro-enterprises empower women borrowers and translate into economic up-liftment. On the other hand, Morduch (1998) argues that micro-credit has only minimal impact on poverty reduction because it rather supports borrowers to create basic incomes instead of driving fundamental 
economic shifts. One reason for these contradicting results could be the indicators that are used to measure impacts because they are influenced by the view of the respective analyst (Duvendack and Maclean 2015). The impact of microcredit on poverty alleviation, for example, is measured based on its impact on income, employment, consumption, asset accumulation, and savings (Al-Mamun et al. 2014b; Khalily 2004). The impact of credit on female empowerment is discussed controversially in the literature. One camp believes that credit programs positively contribute to female empowerment and a variety of empirical results are used to argue this case (Ali and Hatta 2012). A second, more skeptical, viewpoint believes that credit programs do little to alter gender relations in favor of females but in fact may contribute to reinforcing existing gender imbalances (Hasan 2012). As such, it is necessary to find out the impact of micro credit on economic empowerment of women. Recent studies on microfinance in Pakistan (Weber and Ahmad 2014) and in Ethiopia (Haile et al. 2012) found that microfinance provided on a long-term basis increases the economic empowerment of women, yet could not contribute to social empowerment.

According to Rahman (1993), three independent indicators were used to gauge the extent of rural poverty. They are per capita annual income, household's self-evaluation about its economic status, and housing condition. Newer measures use a multidimensional approach that combines a number of indicators and set a threshold for the number of indicators that should not be exceeded (Alkire and Foster 2011a, 2011b). Their ten indicators cover education, health, and the general living standards. Indicators are years of schooling, child school attendance, child mortality, nutrition, electricity, sanitation, drinking water, flooring, cooking fuel, and asset ownership (Alkire et al. 2014). The well-known 'progress out of poverty index' uses ten indicators that focus on education, number of children, daily payment, the situation around housing, and assets including land (Grameen Foundation India 2013). In this paper, the economic status of households has been analyzed through five indicators that are used by the above-mentioned approaches as well, such as landownership, housing, non-land asset ownership, possession of minimum clothing, and self-categorization. With Alkire and Foster (2011a, 2011b) and Weber and Ahmad (2014), we hypothesize that income depends on the amount of land owned or rented, the number of male and female adult members in the family, the value of non-land capital, the number of educated members in the family, and the pressure of subsistence measure by the proxy variable dependency ratio. This hypothesis is in-line with Lanjouw and Ravallion 1995 and Khandker (2005) who posit that the higher the number of dependent per earning person in the family the greater the pressure on the peasant household to work hard to earn the subsistence income.

Hossain (1984) indicates that levels of living standards are determined by income, education, health, clothing, and housing. Therefore, he calculated the living standard index (LSI) of borrowers by allocating the same weight (20\%) to the five LSI indicators. These five indicators were income (IN), health expenditure (HE), condition of housing $(\mathrm{CH})$, number of school-going children (NSGC), and debt from other sources (DFO). The LSI of the benchmark period at the time of joining the NGO was compared with the living standard index of 2001. The difference of the LSI was considered as the poverty alleviation index (PAI). Here we used the indicators of Hossain (1984) as we used debt from other sources instead of clothing indicator to get the numerical data to explain. 
The average LSI for the benchmark period starting 1998 was 815.53 and for the year 2001 it was 1263.77 . The average poverty alleviation index was 448.24. In this paper the impact of the credit of the NGOs on poverty alleviation has been analyzed by fitting regression models with the poverty alleviation index (PAI) for the borrowers' households as dependent variable and considering the amount of loan taken from the NGOs as one of the explanatory variables. It is assumed that the poverty alleviation index (PAI) depends on the income amount of cultivable land (ACL), amount of fixed asset (AFA), number of earning members in the family (NEM), and the amount of the loan (ATL). These connections are presented in Fig. 1.

\section{Objectives}

The present research aims to evaluate the impacts of financing microenterprises by the Bangladeshi NGO-turned-Microfinance institutions such as BRAC, ASA and Proshika on poverty alleviation for sustainable development. More specifically, the study intends to achieve the following objectives:

i) To describe the performance of lending by Bangladesh Rural Advancement Committee (BRAC), Association for Social Advancement (ASA), and PROSHIKA with regard to the alleviation of poverty;

ii) To conduct an econometric analysis to test the hypothesis that financing microentrepreneurial ventures has a statistically significant impact on poverty alleviation;

iii) To identify the bottlenecks in the operations of financing micro entrepreneurs for poverty alleviation.

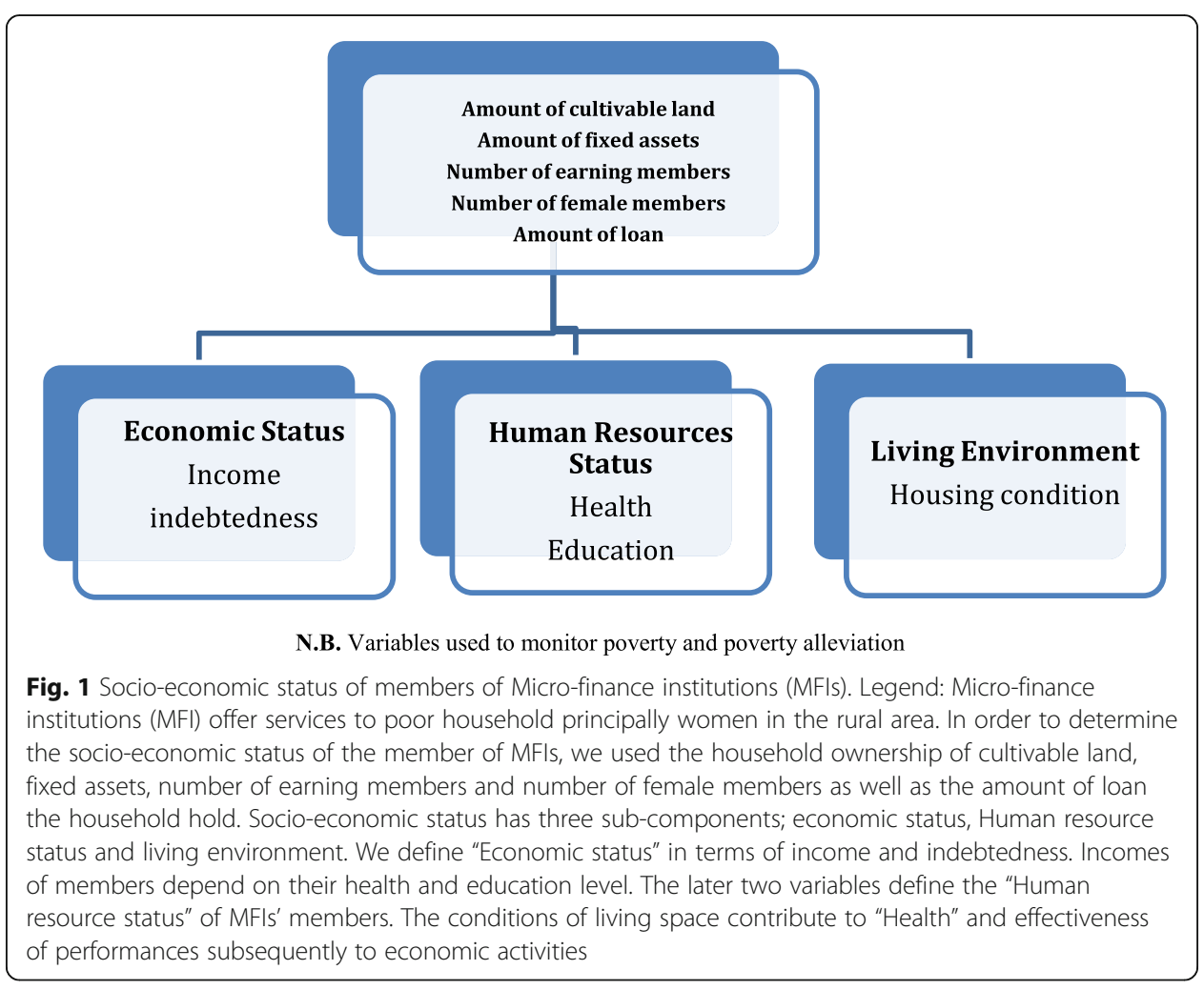


This study will test the following hypothesis:

$\mathrm{H}_{1}$ : The micro-finance (loans) of the three NGO-cum-microfinance institutions (MFIs) has a statistically significant positive impact on poverty alleviation.

\section{Methods}

We have followed some criteria and conditions for collecting data from the samples. In the following sub-sections, we describe each of the items in details.

\section{The study area}

From the six divisional districts of Bangladesh, we selected six villages based on the following criteria:

(i) There must be some activity of BRAC, ASA, and PROSHIKA in the village;

(ii) There is no activity of any other NGO (on that particular village we ensure that no other NGO was working to control the impact of others);

(iii) The period of activity of these three NGO-cum-MFIs in the village must be greater than 3 years.

\section{Sample size determination}

Hossain and Ahmed (2000) report that a slight change in the performance of any of them (BRAC, ASA, PROSHIKA) may affect the total performance of microfinance in Bangladesh as these three MFIs control the $70 \%$ of the total microcredit of Bangladesh. If we assume that the proportion of these MFIs beneficiaries is $70 \%$ of the total number of micro borrowers, the following formula helps us calculate the number of individuals that must be taken as a sample for the proposed study:

$$
n=\left(Z^{2} \cdot p \cdot q\right) / d^{2}
$$

Where:

$\mathrm{p}=$ Prevalence of lack of information about the impact of micro credit on poverty alleviation

$\mathrm{q}=1-\mathrm{p}$

$\mathrm{d}=$ Desired accuracy $=0.05$

$\mathrm{n}=$ Sample size

$\mathrm{z}=1.96$

Therefore, the calculated sample size $=\frac{1.96^{2} * 0.7 * 0.3}{(0.05)^{2}}=323=320$ (approximately).

The respondents of Chittagong and Sylhet district were 40 per district instead of 60 per district, since in these two districts, PROSHIKA was not conducting business for the last 5 years. Therefore, the number of respondents of PROSHIKA were 80 instead of 120 (see Table 1). It was our criteria to select the villages where three NGO-cum-MFIs under consideration is working. We chose the respective villages with the hope of the availability of our data. Yet, during the data collection we realized that 
Table 1 Sample Composition of the Respondents

\begin{tabular}{lllll}
\hline Division, District, Thana & BRAC & ASA & Proshika & Total \\
\hline Chittagong, Comilla, Burichang & 20 & 20 & - & 40 \\
Dhaka, Sherpur, Nakla & 20 & 20 & 20 & 60 \\
Rajshahi, Sirajganj, Shahzadpur & 20 & 20 & 20 & 60 \\
Khulna, Meherpur, Gangni & 20 & 20 & 20 & 60 \\
Barisal, Gournadi & 20 & 20 & 20 & 60 \\
Sylhet, Hobigang, Chunarughat & 20 & 20 & - & 40 \\
Total & 120 & 120 & 80 & 320 \\
\hline
\end{tabular}

PROSHIKA was operating in that two villages in Chittagong and Sylhet. Overall, responses from 320 participants were collected.

\section{Questionnaire}

The main survey instrument, such as questionnaire, was reviewed critically and a pilot survey was conducted in Gazipur district on 20 respondents (borrowers of the selected MFIs) in order to obtain the technical details and conditions of the target sample respondents. For pilot survey, Gazipur district was chosen purposively because of easy communication, and being less time consuming and expensive. In the light of the results of the pilot survey, the questionnaire was finalized for collecting detailed data. The questionnaire consisted of open questions and items with given response alternatives. The latter were designed based on the literature review and the pilot study.

\section{Poverty variables}

Poverty was operationalized using the economic status, measured by the variables of income and indebtedness; human resource status, measured by the variables of health and education; and finally living environment, measured by the variable of housing condition. The variables representing the living standard index and poverty alleviation index were: income, housing condition, number of school-going children, health expenditure, indebtedness and stock type. Information for these variables was collected on a household level to get the aggregate indicators.

\section{Compilation and tabulation of the data}

The collected data was compiled, tabulated and then checked for consistency. Missing data was added by re-visiting the study area.

\section{Mode of analysis}

The tools and techniques used to analyze the data were mostly statistical and econometrical. For the descriptive analysis mean, median, mode, skewness, kurtosis, standard deviation, maximum, minimum, and proportion were used. To analyze heteroskedasticity the White test of heteroskedasticity was conducted. To test the error term the Jarque Berra test was used. Error term distribution anomalies arise when two or more independent variables are highly correlated (Johnston 1984). In such cases, it is hardly possible to distinguish the effects of these variables on the dependent variable (Theil 1971). The PAI equation was estimated through the Ordinary Least Square (OLS) method. 
Multicollinearity was analyzed through a correlation matrix indicating whether there are high and significant correlation coefficients between the independent variables.

For our regression model we used the poverty alleviation index (PAI) as the dependent variable, and the amount of cultivable land (ACL), amount of fixed asset (AFA), number of earning members (NEM), number of male members (MM), number of female members (FM), and amount of loan (AOL).

The model was specified as follows:

$$
\begin{aligned}
& \mathrm{PAI}=\mathrm{f}(\mathrm{ACL}, \mathrm{AFA}, \mathrm{NEM}, \mathrm{MM}, \mathrm{FM}, \mathrm{AOL}) \\
& \mathrm{PAI}=\mathrm{c}+\alpha_{1} \mathrm{ACL}+\alpha_{2} \mathrm{AFA}+\alpha_{3} \mathrm{NEM}+\alpha_{4} \mathrm{MM}+\alpha_{5} \mathrm{FM}+\alpha_{6} \mathrm{AOL}
\end{aligned}
$$

Where:

$\mathrm{ACI}=$ Amount of cultivable land

$\mathrm{AFA}=$ Amount of fixed asset

NEM $=$ Number of earning household members

$\mathrm{MM}=$ Male household members

$\mathrm{FM}=$ Female household members

$\mathrm{AOL}=$ Amount of loan

\section{Results and discussions}

The following section presents the results of our analysis. It will begin with descriptive statistics and presents the results of the inferential statistic and regression analyses in the second part.

\section{Descriptive statistics}

Bangladesh has enormous potentialities in terms of human capital possessing knowledge, skills, ability to labor and good health. Microcredit can enhance the position of a household's income, assets, saving, housing condition in the society. From the field level survey, it was found that $61.67,74.10,60.00 \%$ of the respondents of BRAC, ASA and Proshika respectively could sign the name. Of them, 75.84, 85.83 and $86.25 \%$ respondents are housewife. Out of total family members $64.25,60.77$ and $54.76 \%$ are male, in three cases most of the family have only one earning member. 44.3, 60.00, and $67.5 \%$ respondents reported that they took loan to collect capital but $96,82.5$ and $85 \%$ reported that they spent money for non-business purposes. Out of total respondents $42 \%$ (highest) took loan for three times. 86.67, 65, 86.67\% said that their monthly income has decreased and 68.33, 60 and 69\% said it is for the improper use of the credit. 61.67\% of BRAC's, $74.10 \%$ of ASA's and $60.00 \%$ of Proshika's members were also able to sign their name, indicating their literacy. The majority of the respondents were housewives (BRAC: $75.84 \%$, ASA: $85.83 \%$, Proshika: $86.25 \%$ ). $54.76 \%$ of the family members of Proshika and $64.25 \%$ of ASA's family members were male. Between 44.3 and $67.5 \%$ of the respondents reported that they took loans to collect capital, but between 82.5 and $96 \%$ reported that they spent parts of their loans for non-business purposes. Forty-two percent of the respondents were granted loans three times or more. 86.7\% of BRAC's, ASA: $65.0 \%$ of ASA's and $86.7 \%$ of Proshika's respondents stated that their monthly income has decreased. A majority of them indicated that this happened because of an improper use of the loan. 
The results of the descriptive statistics are presented in Table 2. The average amount of cultivable land is 1.17 acre, the amount of fixed asset is 1134.38 Taka $(\$ 1=70$ Taka on October 4, 2014), the amount of loan per borrower is $14,562.50$ Taka. The mean of female members per family is 2.31 , while the average number of male family members is 2.62 . On average 1.85 members per family earn an income, and the average poverty alleviation index is 448.24. The minimum and maximum amount of cultivable land was 0.4 acre and 3.0 acre respectively. The maximum amount of fixed assets per household was $10,000 \mathrm{Tk}$, the range of the amount of loans was 1000-5000 Tk. The highest number of family members with income per family was 3 with a minimum of 1 , while the average size of a family was 5.3.

What were the drawbacks of microfinance mentioned by the respondents? $60.83 \%$ of BRAC's clients, $16.70 \%$ of the ASA borrowers and $47.50 \%$ of Proshika's clients reported that the biggest problem connected with their loan is the weekly installment. To increase the effectiveness of microcredit on poverty alleviation, $41.25 \%$ of the borrowers suggested that the interest rate should be reduced, $27.36 \%$ responded that the credit installment should be monthly instead of weekly, $14.37 \%$ suggested that an exemption of the service charge would decrease negative effect of microloans, and $12.81 \%$ claimed that an increase of the amount of credit might have a positive impact on poverty alleviation.

\section{Inferential statistics}

We calculated the living standard index (LSI) of the sample borrowers by allocating the same weight (20\%) to the five indicators, income (IN), health expenditure (HE), condition of housing $(\mathrm{CH})$, number of school-going children (NSGC), and debt from others (DFO) (Hossain 1984). The LSI of the benchmark period (1998) at the time of joining the NGO was compared with the living standard index of the study year (2001). The difference of the LSI between the start year and the end year was considered as the poverty alleviation index (PAI). The average LSI for the benchmark period was 815.53. For the year of the study it was 1263.77. Consequently, the living standard index increased by 448.24 .

In order to test the distribution of the residuals, we conducted a Jarque-Bera Test. The test value was 13.03 , with $p=.0014$. The results suggest that that the residual term

Table 2 Descriptive Statistics (ACL: Acre, AFA: Taka, AOL: Taka, FM: Number of Female Members, MM: Number of Male Members, NEM: Number of Earning Members

\begin{tabular}{|c|c|c|c|c|c|c|c|}
\hline & $\mathrm{ACL}$ & AFA & $\mathrm{AOL}$ & FM & MM & NEM & PAI \\
\hline Mean & 1.165 & 1134.381 & $14,562.50$ & 2.312 & 2.6187 & 1.854 & 448.24 \\
\hline Median & 1.000 & 500.000 & $10,000.00$ & 2.000 & 3.000 & 1.000 & 420.20 \\
\hline Maximum & 3.000 & $10,000.00$ & $50,000.00$ & 5.000 & 6.000 & 23.00 & 1914.00 \\
\hline Minimum & 0.400 & 2.000 & 1000.00 & 1.000 & 1.000 & 1.000 & -3939.60 \\
\hline Std. Dev. & 0.664 & 1491.310 & $10,691.86$ & 0.744 & 1.0132 & 1.521 & 433.65 \\
\hline Skewness & 1.096 & 2.522 & 1.354 & 0.978 & 0.580 & 8.620 & -3.07 \\
\hline Kurtosis & 3.282 & 11.205 & 4.567 & 5.046 & 3.302 & 117.820 & 36.33 \\
\hline Observations & 320 & 320 & 320 & 320 & 320 & 320 & 320 \\
\hline
\end{tabular}


is normally distributed (Jarque and Bera 1980) and that the OLS estimation method can be conducted.

The violation of the assumption (iii), which implies constant variance of the disturbance term $\mathrm{u}$, indicates the presence of a heteroskedasticity problem. As a consequence, the OLS estimates become inefficient in both small and large samples (Johnston 1984; Leibenstein 1966). To analyze whether the error term was heteroskedastic, we used the White heteroskedasticity test (White 1980). The results of the White heteroskedasticity test $(\mathrm{F}=1.267628, p=0.17)$ suggest that the $p$-values are not significant. Consequently, we assumed that the error term is homoscedastic and the variance of the error term is constant.

Multicollinearity arises when two or more independent variables are highly correlated (Johnston 1984). In such a case the results of the regression are influenced by the correlation between the independent variables (Theil 1971). Usually, this is indicated by high $R^{2}$ without significant independent variables (Gujarati 1984). The correlation matrix presented in Table 3 demonstrates that the independent variables are not highly correlated with other variables. As such, there is no indication for multicollinearity.

In order to analyze the impact of microloans on poverty alleviation we conducted a linear regression analysis. The estimated equation for our model is:

$$
\begin{gathered}
\mathrm{PAI}=268.836361+42.84744087^{*} \mathrm{ACL}+0.008197716169^{*} \mathrm{AFA}+48.13827^{*} \mathrm{NEM} \\
+31.32180964^{*} \mathrm{MM}-29.76438783^{*} \mathrm{FM}+0.001909632083^{*} \mathrm{AOL}
\end{gathered}
$$

The $\mathrm{r}^{2}$ of the regression is .12 . With $p<.00001$ the regression is significant (see Table 4).

The function suggests that if the amount of land is increased by 1 acre, the poverty alleviation index will increase by 42.85. If the AFA is increased by 1 taka, the PAI will increase by .0082 units. An increase of the number of family members with an income by one, enhances the poverty alleviation index by 48.14 . If the number of male members per family increases by one, the PEI will increase by 31.33 . If the number of female members per family increases by one, the PAI will decrease by 29.76 . If the amount of loan is increased by one taka, the PAI will increase by .0019. All variables, but female family member, have a positive correlation with PAI. The variables FM and AFA, however, did not have significant coefficients.

\section{Conclusion}

The objectives of this study were; (1) to describe the performance of microfinance services offered by the NGO-turned-microfinance institutions such as BRAC, the Association for Social Advancement ASA, and PROSHIKA with regard to the alleviation of

Table 3 Correlation matrix

\begin{tabular}{lllllll}
\hline & ACL & AFA & AOL & FM & MM & NEM \\
\hline ACL & 1 & .312 & .089 & -.020 & .045 & .099 \\
AFA & .312 & 1 & .1062 & -.005 & -.058 & .100 \\
AOL & .089 & .106 & 1 & .006 & -.026 & .023 \\
FM & -.020 & -.005 & .006 & 1 & -.045 & .051 \\
MM & .045 & -.058 & -.026 & -.0452 & 1 & .129 \\
NEM & .00 & .10 & .023 & .0514 & .129 & 1 \\
\hline
\end{tabular}


Table 4 Regression coefficients, std. error, t-statistic and significance of the r4egression model with PAl as dependent variable

\begin{tabular}{lllll}
\hline Variable & Coefficient & Std. Error & t-Statistic & Prob. \\
\hline C & 268.8364 & 72.30932 & 3.717866 & 0.0002 \\
ACL & 42.84744 & 24.05484 & 1.781240 & 0.0758 \\
AFA & 0.008198 & 0.010739 & 0.763348 & 0.4458 \\
NEM & 48.13827 & 10.08153 & 4.774899 & 0.0000 \\
MM & 31.32181 & 15.19855 & 2.060842 & 0.0401 \\
FM & -29.76439 & 20.29325 & -1.466714 & 0.1435 \\
AOL & 0.001910 & 0.001422 & 2.30042 & 0.0223 \\
\hline
\end{tabular}

poverty; (2) to test whether microfinance services for micro-entrepreneurship has a statistically significant impact on poverty alleviation; and (3) to identify the weaknesses of the microfinance programs with regard to poverty alleviation. The results of the OLS estimation that used six independent variables such as amount of cultivable land, amount of fixed asset, number of earning person, number of male person, number of female person and amount of loan, suggest that all the explanatory variables, except the amount of fixed assets and the number of female family members have a significant impact on poverty alleviation. In-line with Hossain (2003), the amount of cultivable land has a significant impact on poverty alleviation because borrowers can utilize their loans to purchase seed, fertilizers, and other agricultural production means to increase their income. Needless to say, a higher the number of earning family members increases the income of families.

Our results demonstrate that MFI's financing of micro-enterprises have a significant positive impact on the poverty alleviation index. If a loan increases by one taka, the poverty alleviation index will improve by 0.002 that is by $0.2 \%$. Though micro-credit has a significant role in poverty alleviation, it is with very low extent. The result is in-line with some other studies. Dutta (1997) indicates that the average absolute reduction in poverty per year has been reasonably high in Bangladesh. A study by Pitt and Khandker (1998) also suggests that microcredit reduces poverty and Roodman and Morduch (2013) found that the micro credit programs they analyzed have improved the living standard of their beneficiaries.

Though we found a significant contribution of microfinance institutions for alleviating poverty, the impact could be stronger. The participants of our study indicated some drawbacks of microfinance, such as high interest rates and weekly installments, prevent a more significant impact on poverty alleviation. Other studies confirm inefficiencies of microfinance institutions due to missing monitoring systems, and lack of well-trained staff (Gutiérrez-Nieto et al. 2007).

To summarize, our research makes three major contributions. First, it extends our knowledge about the impact of microcredit on alleviating poverty. Second, most previous studies on micro-credit have focused on Grameen Bank of Bangladesh (Khalily 2004; Rahman 1999). In contrast, our study evaluated the impacts of micro-credit programs of Bangladeshi MFIs (BRAC, ASA and PROSHIKA) on poverty alleviation. Finally, this paper responds to recent calls for more advanced research on impact of micro-credit in poverty alleviation (Kono and Takahashi 2010; Weiss and Montgomery 2005). 


\section{Acknowledgements}

We appreciate valuable comments from Anonymous reviewers and grateful to them. We are also grateful to Ms. Syeda Sonia Parvin from Thompson Rivers University, BC, Canada, for reading the manuscript several times and point out issues that deserved our attention.

\section{Availability of data and materials}

Please contact authors for data requests.

\section{Authors' contributions}

Equal contribution of each author to the article. All authors read and approved the final manuscript.

\section{Competing interests}

The authors declare that they have no competing interests.

\section{Publisher's Note}

Springer Nature remains neutral with regard to jurisdictional claims in published maps and institutional affiliations.

\section{Author details}

'Department of Marketing Studies and International Marketing, Faculty of Business Administration, University of Chittagong, Chittagong, Bangladesh. ${ }^{2}$ School of Business and Economics, Thompson Rivers University, Kamloops, BC V2C 0C8, Canada. ${ }^{3}$ College of Business, American University of Kurdistan (AUK), Zakho Rd., Sumel, Duhok, Iraq. ${ }^{4}$ Export Development Canada Chair in Environmental Finance School of Environment, Enterprise and Development (SEED) Faculty of Environment, University of Waterloo, 200 University Avenue West, N2L 3G1 Waterloo, ON, Canada.

Received: 16 March 2018 Accepted: 7 September 2018

Published online: 18 September 2018

\section{References}

Ahlin, C., \& Jiang, N. (2008). Can micro-credit bring development. Journal of Development Economics, 86, 1-21. https://doi.org/ 10.1016/j.jdeveco.2007.08.002.

Ahmad, M., \& Townsend, J. (1998). Changing Fortunes in Anti-proverty Programmes In Bangladesh. Journal of International Development, 10, 427-438.

Ahmed, S. (2009). Microfinance Institutions in Bangladesh: Achievements and Challenges. Managerial Finance, 35(12), 9991010. https://doi.org/10.1108/03074350911000052.

Ali, I., \& Hatta, Z. A. (2012). Women's Empowerment or Disempowerment through Microfinance: Evidence from Bangladesh. Asian Social Work and Policy Review, 6(2), 111-121. https://doi.org/10.1111/j.1753-1411.2012.00066.x.

Alkire, S., Conconi, A., \& Seth, S. (2014). Multidimensional Poverty Index 2014: Brief Methodological Note and Results (p. 18). Oxford: The Oxford Poverty and Human Development Initiative (OPHI).

Alkire, S., \& Foster, J. (2011a). Counting and multidimensional poverty measurement. Journal of Public Economics, 95(7-8), 476-487. https://doi.org/10.1016/j.jpubeco.2010.11.006.

Alkire, S., \& Foster, J. (2011b). Understandings and misunderstandings of multidimensional poverty measurement. The Journal of Economic Inequality, 9(2), 289-314. https://doi.org/10.1007/s10888-011-9181-4.

Allet, M., \& Hudon, M. (2013). Green Microfinance: Characteristics of Microfinance Institutions Involved in Environmental Management. Journal of Business Ethics, 1-20. https://doi.org/10.1007/s10551-013-1942-5.

Al-Mamun, A., Mazumder, M., \& Malarvizhi, C. (2014a). Measuring the effect of Amanah Ikhtiar Malaysia's microcredit programme on economic vulnerability among hardcore poor households. Progress in Development Studies, 14(1), 49-59. https://doi.org/10.1177/1464993413504351.

Al-Mamun, A., Mohiuddin, M., \& Mariapun, S. (2014b). Investigating the effects of Amanah Ikhtiar Malaysia's microcredit programmes on employment in rural Malaysia. Journal of Southeast Asian Economies, 31(3), 471-483.

Amin, S., Rai, A., \& Topa, G. (2003). Does microcredit reach the poor and vulnerable? Evidence from northern Bangladesh. Journal of Development Economics, 70, 59-82.

Arora, S., \& Meenu, M. (2011). Women empowerment through microfinance intervention in the commercial banks. International Journal of Economic Research, 2(2), 35-45.

Aubert, C., de Janvry, A., \& Sadoulet, E. (2009). Designing credit agent incentives to prevent mission drift in pro-poor microfinance institutions. Journal of Development Economics, 90(1), 153-162. https://doi.org/10.1016/j.jdeveco.2008. 11.002.

Baklouti, I. (2013). Determinants of Microcredit Repayment: The Case of Tunisian Microfinance Bank. African Development Review, 25(3), 370-382.

Bartual Sanfeliu, C., Cervelló Royo, R., \& Moya Clemente, I. (2013). Measuring performance of social and non-profit Microfinance Institutions (MFIs): An application of multicriterion methodology. Mathematical and Computer Modeling, 57(7-8), 1671-1678. https://doi.org/10.1016/j.mcm.2011.11.010.

Baruah, B. (2010). NGOs in Microfinance: Learning from the Past, Accepting Limitations, and Moving Forward. Geography Compass, 4(8), 979-992. https://doi.org/10.1111/j.1749-8198.2010.00362.x.

Bayulgen, O. (2008). Muhammad Yunus, Grameen Bank and the Nobel Peace Prize: What Political Science Can Contribute to and Learn From the Study of Microcredit. International Studies Review, 10, 525-547.

Brau, J., \& Woller, G. (2004). Microfinance: A Comprehensive Review of the Existing Literature. The Journal of Entrepreneurial Finance and Business Ventures, $9(1), 1-27$.

Bruton, G., Khavul, S., \& Chavez, H. (2011). Micro-lending in emerging economies: Building a new line of inquiry from the ground up. Journal of International Business Studies, 42, 718-739. https://doi.org/10.1057/jibs.2010.58. 
Chatterjee, S., Dutta Gupta, S., \& Upadhyay, P. (2018). Empowering women and stimulating development at bottom of pyramid through micro-entrepreneurship. Management Decision, 56(1), 160-174.

Chokor, B. (2004). Perception and Response to the Challenge of Poverty and Environmental Resource Degradation in Rural Nigeria: Case Study from the Niger Delta. Journal of Environmental Psychology, 24, 305-318.

Chowdhury, A., \& Bhuiya, A. (2004). The Wider Impacts of BRAC Poverty Alleviation Programme in Bangladesh. Journal of International Development, 16, 369-386. https://doi.org/10.1002/jid.1083.

Chowdhury, M. J. A., Ghosh, D., \& Wright, R. E. (2005). The impact of micro-credit on poverty: evidence from Bangladesh. Progress in Development studies, 5(4), 298-309.

Copestake, J. (2007). Mainstreaming microfinance: social performance management or mission drift? World Development, 35(10), 1721-1738.

Cull, R., Demirgüç-Kunt, A., \& Morduch, J. (2007). Financial performance and outreach: a global analysis of leading microbanks The Economic Journal, 117(517), F107-F133. https://doi.org/10.1111/j.1468-0297.2007.02017.X.

Cull, R., Demirgüç-Kunt, A., \& Morduch, J. (2011). Does Regulatory Supervision Curtail Microfinance Profitability and Outreach? World Development, 39(6), 949-965. https://doi.org/10.1016/j.worlddev.2009.10.016.

Datta, D. (2004). Microcredit in Rural Bangladesh: Is It Reaching the Poorest? Journal of Microfinance, 6(1), 55-81.

Develtere, P., \& Huybrecht, A. (2005). The Impact of Microcredit on the Poor in Bangladesh. Alternatives: Global, Local, Political, $30(2), 165-189$

Dowla, A. (2006). In Credit We Trust: Building Social Capital by Grameen Bank in Bangladesh. The Journal of Socio-Economics, $35,102-122$.

Duraiappah, A. (1998). Poverty and Environmental Degradation: A Review and Analysis of the Nexus. World Development, 26(12), 2169-2179.

Dutta, B. (1997). Poverty alleviation and Macroeconomic Policies: Lessons from the Past Experience. In Alleviating Poverty in ASIA. New Delhi: International Labor Organization (ILO).

Duvendack, M., \& Maclean, K. (2015). (Mis)use of evidence in microfinance programming in the global south: a critique. Contemporary Social Science, 10(2), 202-211. https://doi.org/10.1080/21582041.2015.1061686.

Elahi, K., \& Rahman, M. (2006). Micro-credit and Micro-Finance: Functional and Conceptual Differences. Development in Practice, 16(5), 476-483. https://doi.org/10.1080/09614520600792481.

Elkington, J. (1998). Cannibals with forks: the triple bottom line of 21st century business. Gabriola Island: New Society Publishers.

Epstein, M., \& Yuthas, K. (2011). The Critial Role of Trust in Microfinance Success: Identifying Problems and Solutions. Journal of Developmental Entrepreneurship, 16(4), 477-497. https://doi.org/10.1142/S1084946711001951.

Fouillet, C., Hudon, M., Harriss-White, B., \& Copestake, J. (2013). Microfinance Studies: Introduction and Overview. Oxford Development Studies, 42, 1-16. https://doi.org/10.1080/13600818.2013.790360.

Garikipati, S. (2008). The Impact of Lending to Women on Household Vulnerability and Women's Empowerment: Evidence from India. World Development, 36(12), 2620-2642. https://doi.org/10.1016/j.worlddev.2007.11.008.

Grameen Foundation India. (2013). Microfinance: a poverty lens on financial inclusion (p. 50). Gurgaon: Grameen Foundation India C.

Gujarati, D. (1984). Basic Econometrics. New York: McGraw-Hill.

Gutiérrez-Nieto, B., Serrano-Cinca, C., \& Mar Molinero, C. (2007). Microfinance institutions and efficiency. Omega, 35(2), 131142. https://doi.org/10.1016/j.omega.2005.04.001.

Haile, H. B., Bock, B., \& Folmer, H. (2012). Microfinance and female empowerment: Do institutions matter? Women's Studies International Forum, 35(4), 256-265. https://doi.org/10.1016/j.wsif.2012.04.001.

Hartarska, V., \& Nadolnyak, D. (2007). Do Regulated Microfinance Institutions Cchieve Better Sustainability and Outreach? Cross-country Evidence. Applied Economics, 39, 1207-1222.

Hasan, S. (2012). The real efficacy of microfinance sector in addressing women empowerment and poverty alleviation issues in Pakistan. International Journal of Economic Research, 3(4), 174-182.

Hermes, N., \& Lensink, R. (2007a). The empirics of microfinance: what do we know? The Economic Journal, 117(517), F1-F10. https://doi.org/10.1111/j.1468-0297.2007.02013.x.

Hermes, N., \& Lensink, R. (2007b). Impact of Microfinance: A Critical Survey. Economic and Political Weekly, 42(6), 462-465.

Hermes, N., \& Lensink, R. (2011). Microfinance: Its Impact, Outreach, and Sustainability. World Development, 39(6), 875-881. https://doi.org/10.1016/j.worlddev.2009.10.021.

Hermes, N., Lensink, R., \& Meesters, A. (2011). Outreach and Efficiency of Microfinance Institutions. World Development, 39(6), 938-948. https://doi.org/10.1016/j.worlddev.2009.10.018.

Hietalahti, J., \& Linden, M. (2006). Socio-economic Impacts of Microfinance and Repayment Performance: A Case Study of the Small Enterprise Foundation, South Africa. Progress in Development Studies, 6(3), 201-210.

Hishigsuren, G. (2007). Evaluating Mission Drift in Microfinance. Evaluation Review, 31(3), 203-260.

Hossain, F. (2003). The microfinance revolution: Sustainable finance for the poor. American Journal of Agricultural Economics, 85(3), 781-783.

Hossain, K., \& Ahmed, F. (2000). Growth and Dimension of Micro finance Sector in Bangladesh. Paper presented at the Asian Regional Conference, May 23-26, 2000, Kualalumpur, Malaysia.

Hossain, M. (1984). Credit for the rural poor; the experience of Grameen bank in Bangladesh. Dhaka: BIDS.

Hudak, K. (2012). What Next for Microfinance? How the Broader Financial Context Matters for Effective Microfinance Outreach. Journal of Developmental Entrepreneurship, 17(4), 1-18.

Imai, K., Gaiha, R., Thapa, G., \& Annim, S. (2012). Microfinance and Poverty-A Macro Perspective. World Development, 40(8), 1675-1689.

Imai, K. S., Arun, T., \& Annim, S. K. (2010). Microfinance and Household Poverty Reduction: New Evidence from India. World Development, 38(12), 1760-1774. https://doi.org/10.1016/j.worlddev.2010.04.006

Ingham, M., Grafé-Buckens, A., \& Tihon, A. (2013). Bank-Based Microfinance: From Peripheral to Integrated Responsibility Toward Sustainability. Strategic Change, 22(1-2), 107-119. https://doi.org/10.1002/jsc.1925.

Jarque, C. M., \& Bera, A. K. (1980). Efficient tests for normality, homoscedasticity and serial independence of regression residuals. Economics Letters, 6(3), 255-259.

Johnston, J. (1984). Econometric Methods. New York: HcGraw Hill Book Company. 
Kabeer, N. (2001). Conflicts Over Credit: Re-Evaluating the Empowerment Potential of Loans to Women in Rural Bangladesh. World Development, 29(1), 63-84. https://doi.org/10.1016/S0305-750X(00)00081-4.

Karim, L. (2008). Demystifying Micro-Credit: The Grameen Bank, NGOs, and Neoliberalism in Bangladesh. Cultural Dynamics, 20(1), 5-29. https://doi.org/10.1177/0921374007088053.

Karim, R., \& Osada, M. (1998). Dropping Out: An Emerging Factor in the Success of Microcredit-based Proverty Alliviation Programs. The Developing Economics, XXXVI(3), 257-288.

Khalily, M. A. B. (2004). Quantitative approach to impact analysis of microfinance programmes in Bangladesh-what have we learned? Journal of International Development, 16(3), 331-353. https://doi.org/10.1002/jid.1081.

Khan, A. (1995). Sustainable development: The key concepts, issues and implications. Sustainable Development, 3, 63-69.

Khanam, D., Parvin, S. S., Mohiuddin, M., Hoque, A., \& Su, Z. (2018). Financial Sustainability of Non-Governmental Microfinance Institutions (MFIs): A Cost-Efficiency Analysis of BRAC, ASA, and PROSHIKA from Bangladesh. Review of Economics \& Finance, 12(2), 43-56.

Khandker, S. R. (1998). Fighting poverty with microcredit: experience in Bangladesh. New York; Oxford: Oxford University Press.

Khandker, S. R. (2005). Microfinance and poverty: Evidence using panel data from Bangladesh. The World Bank Economic Review, 19(2), 263-286.

Knight, T., Hossain, F., \& Rees, C. (2009). Microfinance and the commercial banking system: perspectives from Barbados. Progress in Development Studies, 9(2), 115-125. https://doi.org/10.1177/146499340800900203.

Komatsu, S., Kaneko, S., \& Ghosh, P. P. (2011). Are micro-benefits negligible? The implications of the rapid expansion of Solar Home Systems (SHS) in rural Bangladesh for sustainable development. Energy Policy, 39(7), 4022-4031. https://doi.org/10. 1016/j.enpol.2010.11.022.

Kono, H., \& Takahashi, K. (2010). Microfinance Revolution: Its Effects, Innovations, and Challenges. The Developing Economies, 48(9), 15-73. https://doi.org/10.1111/j.1746-1049.2010.00098.x.

Koveos, P., \& Randhawa, D. (2004). Financial Services for the Poor: Assessing Microfinance Institutions. Managerial Finance, 30(9), 70-94.

Lanjouw, P., \& Ravallion, M. (1995). Poverty and Household Size. The Economic Journal, 105(433), 1415-1434. https://doi.org/10. $2307 / 2235108$

Leibenstein, H. (1966). Allocative Efficiency versus X-efficiency. American Economic Review, 56, 392-415.

Lock, R., \& Lawton Smith, H. (2016). The impact of female entrepreneurship on economic growth in Kenya. International Journal of Gender and Entrepreneurship, 8(1), 90-96.

Mallick, R. (2002). Implementing and evaluating microcredit in Bangladesh. Development in Practice, 12(2), 153-163.

Martin, I., \& Hulme, D. (2003). Programs for the Poorest: Learning from the IGVGD Program in Bangladesh. World Development, $31(3), 647-665$.

Matin, I., Hume, D., \& Rutherford, S. (2002). Finance For The Poor: From Microcredit To Financial Services. Journal of International Development, 14, 273-294. https://doi.org/10.1002/jid.874.

Mayoux, L. (2001). Tackling the Down Side: Social Capital, Women's Empowerment and Micro-Finance in Cameroon. Development and Change, 32(3), 435-464.

Mazumder, M., \& Wencong, L. (2013). Micro-Credit and Poverty Reduction: A Case of Bangladesh. Prague Economic Paper, 3, 403-417.

Mersland, R., \& Strøm, R. Ø. (2010). Microfinance Mission Drift? World Development, 38(1), 28-36. https://doi.org/10.1016/j. worlddev.2009.05.006.

Mohiuddin, M. (2000). Le micro-crédit dans l'éradication de la pauvreté (In french). Cahiers Africain d'Administration Publique, $55,105-119$.

Morduch, J. (1998). Does Micro finance Really Help the Poor: New Evidence from Flagship Programs in Bangladesh. In Hoover Institution. Stanford: Stanford University.

Morgan, J. P. (2010). Impact Investments: an emerging asset class (p. 96). New York: J.P. Morgan Global Research and Rockefeller Foundations.

Muhumuza, W. (2005). Unfulfilled Promises? NGOs' Micro-Credit Programmes and Poverty Reduction in Uganda. Journal of Contemporary African Studies, 23(3), 392-416. https://doi.org/10.1080/01426390500273858.

Nanda, P. (1999). Women's participation in rural credit programmes in Bangladesh and their demand for formal health care: is there a positive impact? Health Economics, 8(5), 415-428. https://doi.org/10.1002/(sici)1099-1050(199908)8:5<415::aidhec450>3.0.co;2-I.

Nawaz, S. (2010). Microfinance and Poverty Reduction: Evidence from a Village Study in Bangladesh. Journal of Asian and African Studies, 44(6), 670-683.

Pitt, M., \& Khandker, S. (1998). The Impact of Group-Based Credit Programs on Poor Households in Bangladesh: Does the Gender of Participants Matter. Journal of Political Economy, 106(5), 958-996.

Pitt, M., Khandker, S., Mckernan, S., \& Latif, M. (1999). Credit Programs for the Poor and Reproductive Behavior in Low-income Countres : Reported Causal Relationships the Result of Heterogeneity Bias? Demography, 36(1), 1-21.

Pollinger, J., Outhwaite, J., \& Cordero-Guzmán, H. (2007). The Question of Sustainability forMicrofinance Institutions. Journal of Small Business Management, 45(1), 23-41.

Quayes, S. (2012). Depth of outreach and financial sustainability of microfinance institutions. Applied Economics, 44, $3421-$ 3433.

Rahman, A. (1999). Micro-credit initiatives for equitable and sustainable development: Who pays? World Development, 27(1), 67-82. https://doi.org/10.1016/S0305-750X(98)00105-3.

Rahman, Z. (1993). Monitoring adjustment and poverty: Methodological and empirical issues in rural poverty analysis in Monitoring Adjustment and poverty in Bangladesh: Report on the Framework Project. Dhaka: CIRDAP.

Rankin, K. (2002). Social Capital, Microfinance, and the Politics of Development. Feminist Economics, 8(1), 1-24.

Reardon, T., \& Vosti, S. (1995). Links between rural poverty and the environment in developing countries: asset categories and investment poverty. World Development, 23(9), 1495-1506 https://doi.org/10.1016/0305-750X(95)00061-G.

Robinson, M. S. (2001). The Microfinance Revolution. Washington, D.C.: World Bank.

Roodman, D., \& Morduch, J. (2009). The impact of microcredit on the poor in Bangladesh: Revisiting the evidence (p. 50). Washington, DC: Center for Global Development. 
Roodman, D., \& Morduch, J. (2013). The Impact of Microcredit on the Poor in Bangladesh: Revisiting the Evidence. The Journal of Development Studies, 1-21. https://doi.org/10.1080/00220388.2013.858122.

Rosintan, D., Drioadisuryo, P., \& Cloud, K. (1999). Gender, Self-employment and Microcredit Programs An Indonesian Case Study. The Quarterly Review of Economics and Finance, 39, 769-779.

Ruben, R., \& Van, M. (2001). Nonfarm Employment and Poverty Alleviation of Rural Farm Households in Honduras. World Development, 29(3), 549-560.

Schuler, S. R., \& Rottach, E. (2010). Women's Empowerment across Generations in Bangladesh. The Journal of Development Studies, 46(3), 379-396. https://doi.org/10.1080/00220380903318095.

Smyth, I. (2007). Talking of Gender: Words and Meanings in Development Organisations. Development in Practice, 17(4-5), $582-588$.

Swibel, M. (2008, 07/2008). Microfinance Fever. Forbes, 181(1), 50 [Jan 1, 2008].

Theil, H. (1971). Principles of Econometrics. New York: Wiley.

Ullah, A., \& Routray, J. (2007). Rural Poverty Alleviation through NGO Interventions in Bangladesh: How Far is the Achievement? International Journal of Social Economics, 34(7), 237-248.

UN (2015). Transforming our World: The 2030 Agenda for Sustainable Development. https://sustainabledevelopment.un.org/ post2015/transformingourworld/publication. Access on 10 January 2018.

UNDP. (2015). Human Development Index Report, 2015. New York: UNDP.

Vial, V., \& Hanoteau, J. (2015). Returns to micro-entrepreneurship in an emerging economy: A quantile study of entrepreneurial Indonesian households' welfare. World Development, 74, 142-157.

Weber, O. (2013). Impact Measurement in Microfinance: Is the measurement of the Social Return on Investment an Innovation in Microfinance? Journal of Innovation Economics, 11, 149-171.

Weber, O., \& Ahmad, A. (2014). Empowerment Through Microfinance: The Relation Between Loan Cycle and Level of Empowerment. World Development, 62, 75-87. https://doi.org/10.1016/j.worlddev.2014.05.012.

Weiss, J., \& Montgomery, H. (2005). Great Expectations: Microfinance and Poverty Reduction in Asia and Latin America. Oxford Development Studies, 33(3-4), 391-416. https://doi.org/10.1080/13600810500199210.

White, H. (1980). A heteroskedasticity-consistent covariance matrix estimator and a direct test for heteroskedasticity. Econometrica: Journal of the Econometric Society, 48(4):817-838.

Yaron, J. (1992). Assessing Development Finance Institutions - A Public Interest Analysis. Washington, DC: World Bank.

Zapalska, A., Stodder, J., \& Wingrove-Haugland, E. (2017). Female Micro-Entrepreneurship: The Key to Economic Growth and Development in Islamic Economies. In Entrepreneurship and Management in an Islamic Context (pp. 179-206). Cham: Springer.

Zeller, M., Sharma, M., Ahmed, A., \& Rashid, S. (2001). Group-based financial institutions for the rural poor in Bangladesh: An institutional- and household-level analysis (pp. 97-100). Washington: International Food Policy Research Institute (IFPRI)

\section{Submit your manuscript to a SpringerOpen ${ }^{\circ}$ journal and benefit from:}

- Convenient online submission

Rigorous peer review

- Open access: articles freely available online

High visibility within the field

- Retaining the copyright to your article

Submit your next manuscript at $\boldsymbol{\nabla}$ springeropen.com 